\title{
Detection and Molecular Characterization of Two Little Leaf Phytoplasma Strains Associated with Pepper and Tomato Diseases in Guanajuato and Sinaloa, Mexico
}

\author{
M. E. Santos-Cervantes, CIIDIR-IPN, Unidad Sinaloa, Juan de Dios Bátiz Paredes No. 250, Guasave, Sinaloa, \\ México CP 81101, and Programa Regional del Noroeste para el Doctorado en Biotecnología, FCQB-UAS. Cd. Uni- \\ versitaria, AP 1354, Culiacán, Sinaloa, México; and J. A. Chávez-Medina, J. Méndez-Lozano, and N. E. Leyva- \\ López, CIIDIR-IPN, Unidad Sinaloa, Juan de Dios Bátiz Paredes No. 250, Guasave, Sinaloa, México CP 81101
}

\begin{abstract}
Santos-Cervantes, M. E., Chávez-Medina, J. A., Méndez-Lozano, J., and Leyva-López, N. E. 2008. Detection and molecular characterization of two little leaf phytoplasma strains associated with pepper and tomato diseases in Guanajuato and Sinaloa, Mexico. Plant Dis. 92:1007-1011.

Pepper (Capsicum annuum) and tomato (Lycopersicon esculentum) are important vegetable crops in Mexico. Recently, symptoms associated with phytoplasma diseases such as witches'broom (shoot proliferation) and little leaf were observed in pepper and tomato fields in central and northwestern Mexico. DNA extracted from symptomatic and asymptomatic plants was used in nested polymerase chain reaction (PCR) assays with primers amplifying 16S rDNA sequences for phytoplasmas. Twenty-four percent of pepper and $49 \%$ of tomato samples yielded a nested rDNA product of $1.25 \mathrm{~kb}$. Restriction fragment length polymorphism profiles and sequencing of PCR products allowed classification of the detected phytoplasmas with the aster yellows group (16SrI). Both phytoplasmas, pepper little leaf (PeLL) and tomato little leaf (ToLL), could be included as new members of the aster yellows group because HaeIII and TaqI restriction enzymes discriminated among these phytoplasmas and members of other 16SrI subgroups. PeLL and ToLL phytoplasma sequences were deposited and compared with those in GenBank, and the maximum identity was found with several isolates of 'Candidatus Phytoplasma asteris'. The highest identity (99\%) has been observed with tomatillo little leaf phytoplasma and ash witches'-broom phytoplasma. This is the first report of ' $\mathrm{Ca}$. Phytoplasma asteris' associated with pepper and tomato diseases in the Mexican states of Guanajuato and Sinaloa.
\end{abstract}

Additional keyword: RFLP-PCR

Pepper (Capsicum annuum) and tomato (Lycopersicon esculentum Mill.) are important vegetable crops in Mexico. The national production of pepper and tomato in 2005 to 2006 was 2.1 and 2.25 million metric tons with a value of US\$938 million and US\$944 million, respectively (34). Increased market demand has contributed to more intensive production of different pepper and tomato varieties. However, due to occurrence of insect pests and disease problems, the yield and quality of the fruit are lower than expected, causing heavy economic losses. Recently, symptoms associated with phytoplasma diseases such as witches'-broom (shoot

Corresponding author: N. E. Leyva-López

E-mail: neleyval@ipn.mx

Accepted for publication 21 December 2007.

doi:10.1094/PDIS-92-7-1007

This article is in the public domain and not copyrightable. It may be freely reprinted with customary crediting of the source. The American Phytopathological Society, 2008. proliferation) and little leaf were observed in pepper and tomato crops.

Phytoplasma diseases of potato (Solanum tuberosum), tomato (Lycopersicon esculentum), tomatillo (Physalis ixocarpa), ornamental plants (Catharanthus roseus, Opuntia spp., Alstroemeria sp.), Cempazuchil (marigold, Tagetes erecta), Pigeon pea (Cajanus cajan), lima bean (Phaseolus lunatus), coconut palms (Cocos nucifera), and weeds (Vinca minor, Trifolium spp., Amaranthus hibridus) have been reported in Mexico (2,9,16,17,26-31).

Phytoplasmas are bacteria without cell walls that inhabit plant phloem. They are poorly understood plant pathogens because they cannot be cultured in vitro. Until recently, they were identified and classified based on symptomatology, host range, and vector specificity, but these methods are not suitable to reveal the genetic relatedness among different phytoplasmas (23). DNA-based molecular techniques such as polymerase chain reaction (PCR), restriction fragment length polymorphism (RFLP) analysis of PCR products, and sequence analysis have been recently used to detect and differentiate phytoplasma strains $(15,23,27,33,36)$. To date, 18 groups and more than 40 subgroups of phytoplasmas have been delineated based on RFLP analysis of $16 \mathrm{~S}$ rDNA sequences, and 26 Candidatus Phytoplasma species have been proposed $(5,6,18,21,23,38)$. The 'Candidatus Phytoplasma asteris' concept encompasses all known subgroups within group 16SrI (aster yellows group). It is the largest phylogenetic group, with approximately 15 subgroups. Subgroups 16SrI-A, 16SrI-B, and 16SrI-C are distributed worldwide and are associated with more than 80 plant species. Subgroups $16 \mathrm{SrI}-\mathrm{L}$ and 16SrI-M appear to be restricted to Europe. The subgroup 16SrI-D is found only in Asia. Subgroup 16SrI-B represents the largest and most diverse strain cluster in the group (25). In Mexico, the phytoplasma causing the diseases "filodia del cempazuchil" and "permanent yellowing" of tomato belongs to subgroup 16SrI-B. The potato purple top phytoplasma associated with potato diseases is considered to be a new member of the aster yellows group based on RFLP and sequence analysis of the $16 \mathrm{~S}$ rDNA $(16,27,30)$.

Phytoplasma diseases of pepper have been reported in Spain (8), Australia (37), India (20), and Cuba (7). Phytoplasma diseases of tomato have been reported from several areas in the Mediterranean Basin $(1,4,10,11,39,41)$, the United States (22,24,35), Australia (13,32), Bolivia (19), and Brazil (3). However, there is little information about phytoplasma diseases of pepper and tomato in Mexico. To our knowledge, this is the first report of ' $\mathrm{Ca}$. Phytoplasma asteris' associated with pepper and tomato diseases in the Mexican states of Guanajuato and Sinaloa.

\section{MATERIALS AND METHODS}

Plant samples. Pepper and tomato plants showing symptoms of witches'broom (shoot proliferation) and little leaf were collected in the Mexican states of Guanajuato and Sinaloa. A total of 63 pepper samples and 101 tomato samples were collected during 2002 to 2005 .

DNA extraction. A procedure modified from Zhang et al. (40) was used for DNA extraction from pepper and tomato tissues. 
Two hundred milligrams of actively growing fresh leaf tissue was ground in hot hexadecyltrimethylammonium bromide (CTAB) buffer (3\% CTAB, $1.4 \mathrm{M}$ $\mathrm{NaCl}, 20 \mathrm{mM}$ EDTA, $100 \mathrm{mM}$ Tris- $\mathrm{HCl}$, pH 8.0, 0.2\% mercaptoethanol).

Phytoplasma detection by PCR. Two "universal" phytoplasma-specific nested primers were used for the detection of phytoplasma. The primers $\mathrm{R} 16 \mathrm{mF} 2 /$ $\mathrm{R} 16 \mathrm{mR} 1$ and $\mathrm{R} 16 \mathrm{~F} 2 \mathrm{n} / \mathrm{R} 16 \mathrm{R} 2$ were used to amplify a portion of the $16 \mathrm{~S}$ rDNA (14). Primers R16mF2/R16mR1 amplify a DNA fragment of $1.45 \mathrm{~kb}$, whereas primers R16F2n/R16R2 amplify a fragment of 1.25 $\mathrm{kb}$. PCR amplifications were conducted in an automated thermocycler (model Icycler, Bio-Rad, USA) with one unit of Taq DNA polymerase (Invitrogen Life Technologies, Brazil) in a volume of $25 \mu$ containing 100 ng of total DNA, $200 \mathrm{mM}$ each dNTP, and $0.4 \mathrm{pmol} / \mu \mathrm{l}$ each primer. The reaction was conducted with one cycle of $4 \mathrm{~min}$ at $94^{\circ} \mathrm{C}$ followed by 35 cycles of $1 \mathrm{~min}$ at $94^{\circ} \mathrm{C}, 1$ min at $60^{\circ} \mathrm{C}\left(55^{\circ} \mathrm{C}\right.$ for $\left.\mathrm{R} 16 \mathrm{~F} 2 \mathrm{n} / \mathrm{R} 16 \mathrm{R} 2\right), 3$ min at $72^{\circ} \mathrm{C}$, and an additional cycle of 5 min at $72^{\circ} \mathrm{C}$. PCR products were analyzed by electrophoresis in a $1 \%$ agarose gel and visualized by staining with ethidium bromide and UV illumination. DNA samples extracted from pepper and tomato plants were used as template for PCR. DNA extracted from asymptomatic plants and sterile water were used as negative controls. Total genomic DNA from a previously characterized phytoplasma infecting Opuntia spp. was used as a positive control (26).

RFLP analysis of detected phytoplasma. Fragments of $16 \mathrm{~S}$ rDNA from

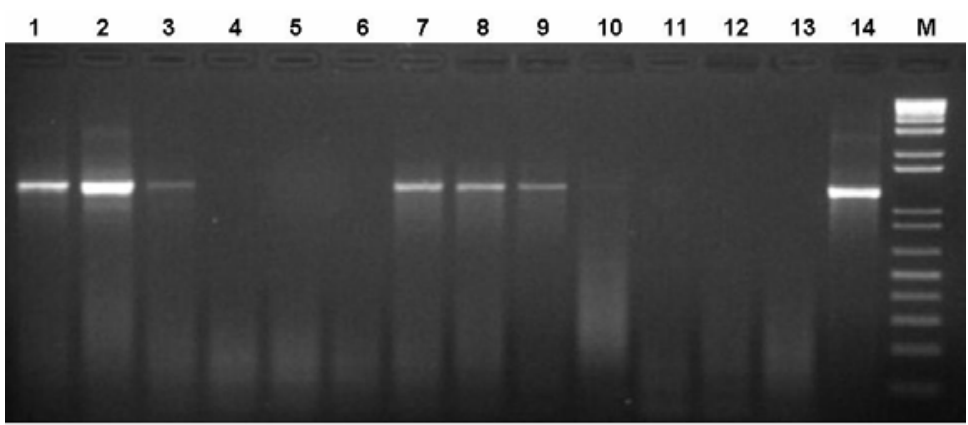

Fig. 1. Gel electrophoresis of products from polymerase chain reaction (PCR) performed on DNA extracted from pepper and tomato samples using nested-PCR with primers pairs R16mF2R16mR1/R16F2n-R16R2. Lane M, $1 \mathrm{~kb}$ plus DNA ladder (Invitrogen Life Technologies); lanes 1 to 6, pepper samples; lanes 7 to 12, tomato samples; lane 13, negative control (water); lane 14, positive control.

pepper little leaf (PeLL) and tomato little leaf (ToLL) phytoplasmas amplified by nested PCR with the primer pairs $\mathrm{R} 16 \mathrm{mF} 2 / \mathrm{R} 16 \mathrm{mR} 1$ and $\mathrm{R} 16 \mathrm{~F} 2 \mathrm{n} / \mathrm{R} 16 \mathrm{R} 2$ from at least 10 different symptomatic leaf samples were digested with AluI, HpaII, KpnI, HaeIII, HhaI, TaqI, MseI, RsaI, and $B f a \mathrm{I}$ according to the manufacturer's instructions (Invitrogen Life Technologies, USA). The digestion products were then fractionated by electrophoresis using $3 \%$ agarose gels and stained in ethidium bromide. RFLP patterns were compared with previous results (24).

Cloning of PCR products and sequencing of DNA. Two PCR products from PeLL phytoplasma and ToLL phytoplasma were purified using a Genclean III kit (Gibco-BRL) and ligated onto the pGEM-T vector (Promega Corporation). The ligation mixture was used to transform Escherichia coli DH5 $\alpha$ (Promega). Plasmid DNA from cultures of recombinant colonies was purified using QIAprep Spin Miniprep Kit (QIAGEN GmbH). Both strands of two different clones of each phytoplasma were sequenced completely in an ABI PRISM 377 sequencer using the Dye cycle sequencing kit (Applied Biosystems, Foster City, CA). The sequences of 16S rDNA from PeLL phytoplasma and ToLL phytoplasma have been assigned the GenBank accession numbers DQ092321 and DQ375238, respectively.

Sequence similarity analysis and in silico enzyme digestions. The $16 \mathrm{~S}$ rDNA sequence similarities between strains were evaluated after alignments were generated
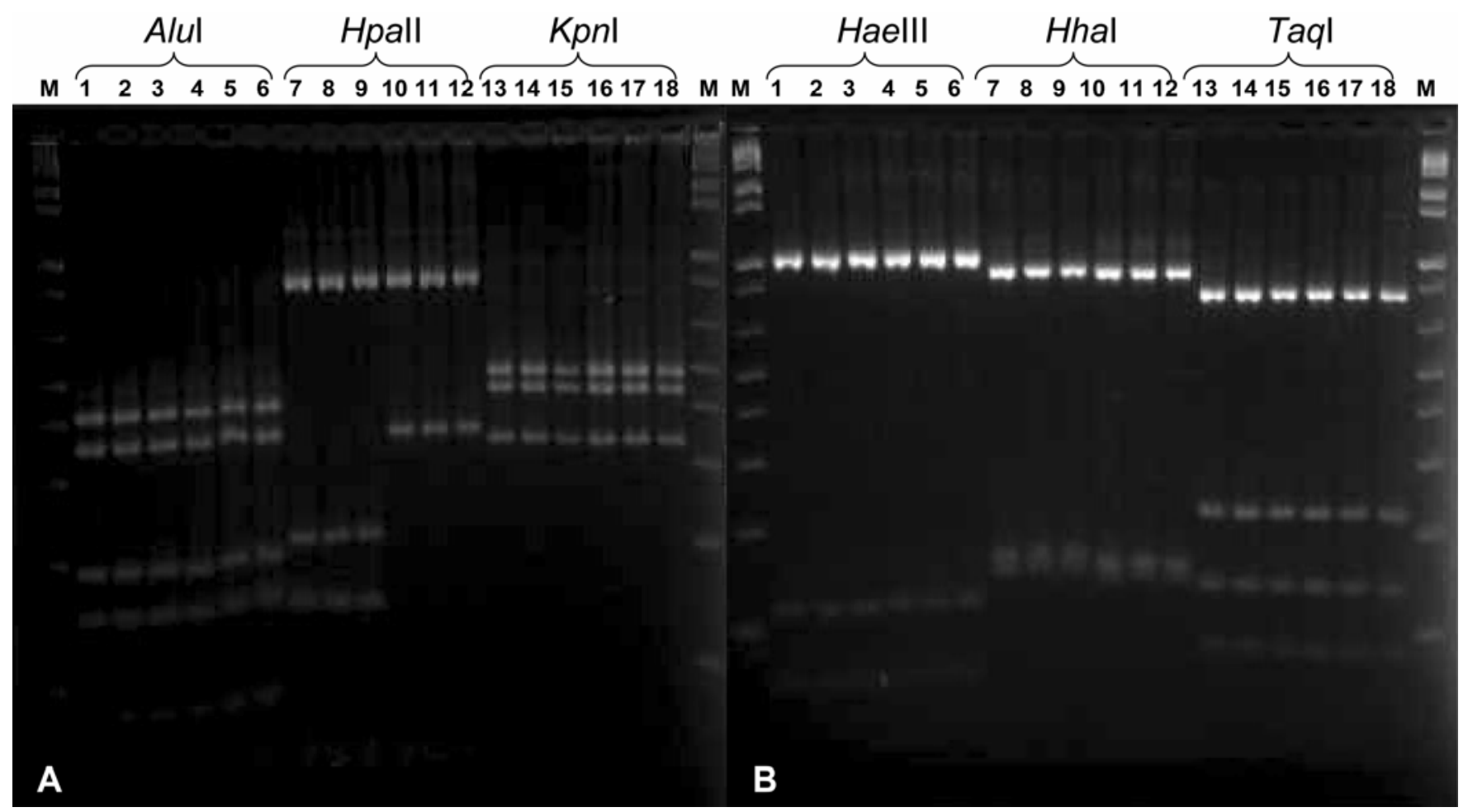

Fig. 2. Restriction endonuclease digestion profiles of nested (R16mF2/R16mR1 and R16F2n/R16R2) polymerase chain reaction (PCR) products. Lanes 1 to 3, 7 to 9, 13 to 15, represent pepper little leaf, and lanes 4 to 6, 10 to 12,16 to 18, tomato little leaf samples digested with AluI, HpaII, KpnI (A) and HaeIII, HhaI, TaqI (B) enzymes. Lane M, 1 kb plus DNA ladder (Invitrogen Life Technologies). 
using the Clustal W method of the MegAlign program (DNASTAR Inc., Madison, WI). Virtual restriction fragment analysis was performed from the partial sequences of the 16S rDNA gene using the virtual gel plotting program pDRAW32 (AcaClone). Each aligned DNA fragment was digested in silico with nine distinct restriction enzymes (AluI, HpaII, KpnI, HaeIII, HhaI, TaqI, MseI, RsaI, and BfaI) that have been routinely used for phytoplasma 16S rRNA gene RFLP analysis.

Phylogenetic analysis. Nearly complete 16S rDNA sequences from PeLL and ToLL phytoplasmas, along with 19 known phytoplasmas and Acholeplasma palmae, were aligned using the Clustal $\mathrm{X}$ method of the MegAlign program. The phylogenetic tree was generated using the Njplot program from Clustal X. A. palmae was employed as the outgroup to root the tree. Bootstrapping was performed to estimate the stability and support for the branches.

\section{RESULTS}

Detection of phytoplasmas from pepper and tomato plants. Phytoplasmas were detected by nested PCR with universal primer pairs $\mathrm{R} 16 \mathrm{~F} 2 \mathrm{n} / \mathrm{R} 16 \mathrm{R} 2$ and $\mathrm{R} 16 \mathrm{mF} 2 / \mathrm{R} 16 \mathrm{mR} 1$ in 15 out of 63 samples and 49 out of 101 samples from pepper and tomato, respectively. Typical bands of $1.25 \mathrm{~kb}$ were visualized in agarose gels for DNA extracted from pepper, tomato, and the positive control (Fig. 1). No amplification was observed when DNA from asymptomatic plants was used as template (data not shown).

RFLP analysis. To identify phytoplasma isolates infecting pepper and tomato plants, products from nested PCR (R16F2n/R16R2) amplification of 10 different plant samples were digested with AluI, HpaII, KpnI, HaeIII, HhaI, TaqI, $M s e \mathrm{I}, R s a \mathrm{I}$, and $B f a \mathrm{I}$ (RFLP patterns obtained from AluI, HpaII, KpnI, HaeIII, HhaI, and TaqI of three pepper and tomato samples are shown in Figure 2). All the samples tested of each phytoplasma showed the same profile. The KpnI restriction patterns of DNA from phytoplasmas detected in tomato and pepper were identical to the predicted RFLP profiles of potato purple top phytoplasma (PPT) (type strain of ' $\mathrm{Ca}$. Phytoplasma asteris') and other previously described phytoplasmas of the 16SrI group (24,27). HaeIII and TaqI digests of PeLL and ToLL fragments were identical, but were different from other members of the 16SrI group (24). HhaI digests of PeLL and ToLL fragments were identical to those predicted for members of the subgroup 16SrI-B (24). However, the ToLL phytoplasma was distinguished from the PeLL phytoplasma and other members of the 16SrI group by its HpaII digestion pattern (Fig. 2A).

Nucleotide sequence analysis and in silico enzyme digestions. The sequences of the $1.25-\mathrm{kb}$ PCR fragment of the $16 \mathrm{~S}$ rDNA of PeLL and ToLL phytoplasmas were compared with those in the NCBI/GenBank database, and the maximum identity was found with several isolates of the aster yellows, 16SrI, group (' $\mathrm{Ca}$. Phytoplasma asteris'). The highest identity was observed with tomatillo little leaf phytoplasma $(99.3$ and $99.6 \%$, respectively, GenBank accession number DQ987871) and ash witches'-broom (99.1 and $99.5 \%$, respectively, GenBank acces-
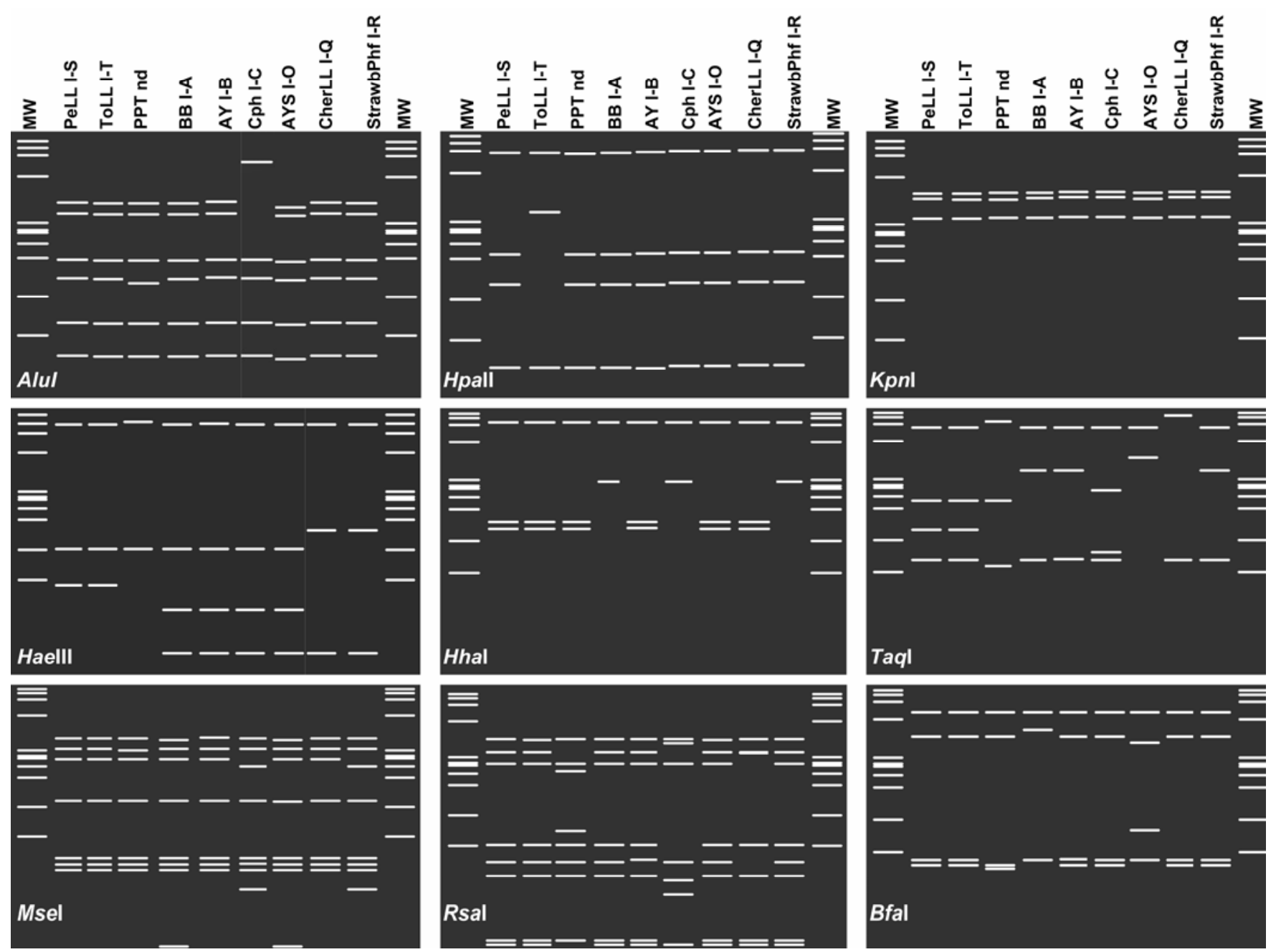

Fig. 3. Virtual restriction fragment length polymorphism (RFLP) patterns from in silico digestions of 16S rRNA gene F2nR2 fragments from pepper and tomato little leaf phytoplasmas and seven phytoplasma strains representing different subgroups of aster yellows group (16SrI). Nine restriction enzymes were used in the digestions: AluI, HpaII, KpnI, HaeIII, HhaI, TaqI, MseI, RsaI, and BfaI. MW, $\varphi$ X174DNA-HaeIII digestion. Virtual RFLP patterns were generated using the gel plotting program pDRAW32. 
sion number AY566302). Ash witches'broom belongs to the 16SrI group of phytoplasmas (aster yellows), subgroup B (24). Sequence identities of the PeLL and ToLL 16S rDNA were 99 and $99.4 \%$, respectively, with different strains of aster yellows (16SrI, subgroups $\mathrm{B}, \mathrm{M}$, and $\mathrm{N}$, GenBank accession numbers AY180943, AY265209, and AY265205, respectively); and less identity, 98.5 and $98.8 \%$, respectively, was found with soybean purple top number AF268405) (24). The rDNA sequences of PeLL and ToLL phytoplasmas were distinct from those of potato purple top (PPT) associated with potato diseases in Mexico (98.4 and 98.8\%, respectively) (27).

Virtual RFLP patterns (Fig. 3) revealed differences between PeLL and ToLL and others strains of ' $\mathrm{Ca}$. Phytoplasma asteris' used. The PeLL and ToLL phytoplasmas showed TaqI and HaeIII restriction patterns different from all the described members of the $16 \mathrm{SrI}$ group. AluI, HaeIII, (16SrI, subgroup O, GenBank accession

TaqI, RsaI, and $B f a \mathrm{I}$ restriction patterns of PeLL and ToLL were different from PPT phytoplasma. The PeLL and ToLL phytoplasmas can be differentiated by the restriction enzyme HpaII, and ToLL has a unique restriction pattern among phytoplasmas previously classified in the $16 \mathrm{SrI}$ group (24). Therefore, we designated PeLL and ToLL phytoplasmas as new subgroups $\mathrm{S}$ and $\mathrm{T}$ (16SrI-S and 16SrI-T, respectively) following criteria reported by Lee et al. (24).

Phylogenetic analysis. The $16 \mathrm{~S}$ rDNA sequences of the PeLL and ToLL phytoplasmas compared with those of 18 other phytoplasmas and A. palmae yielding the consensus tree are illustrated in Figure 4. The bootstrapping values indicated strong support for most branches. PeLL and ToLL phytoplasmas give rise to new branches not seen in previous phylogenetic trees, indicating that these phytoplasmas may represent a new phytoplasma lineage, and supporting the designation of PeLL and ToLL phytoplasmas as representative of

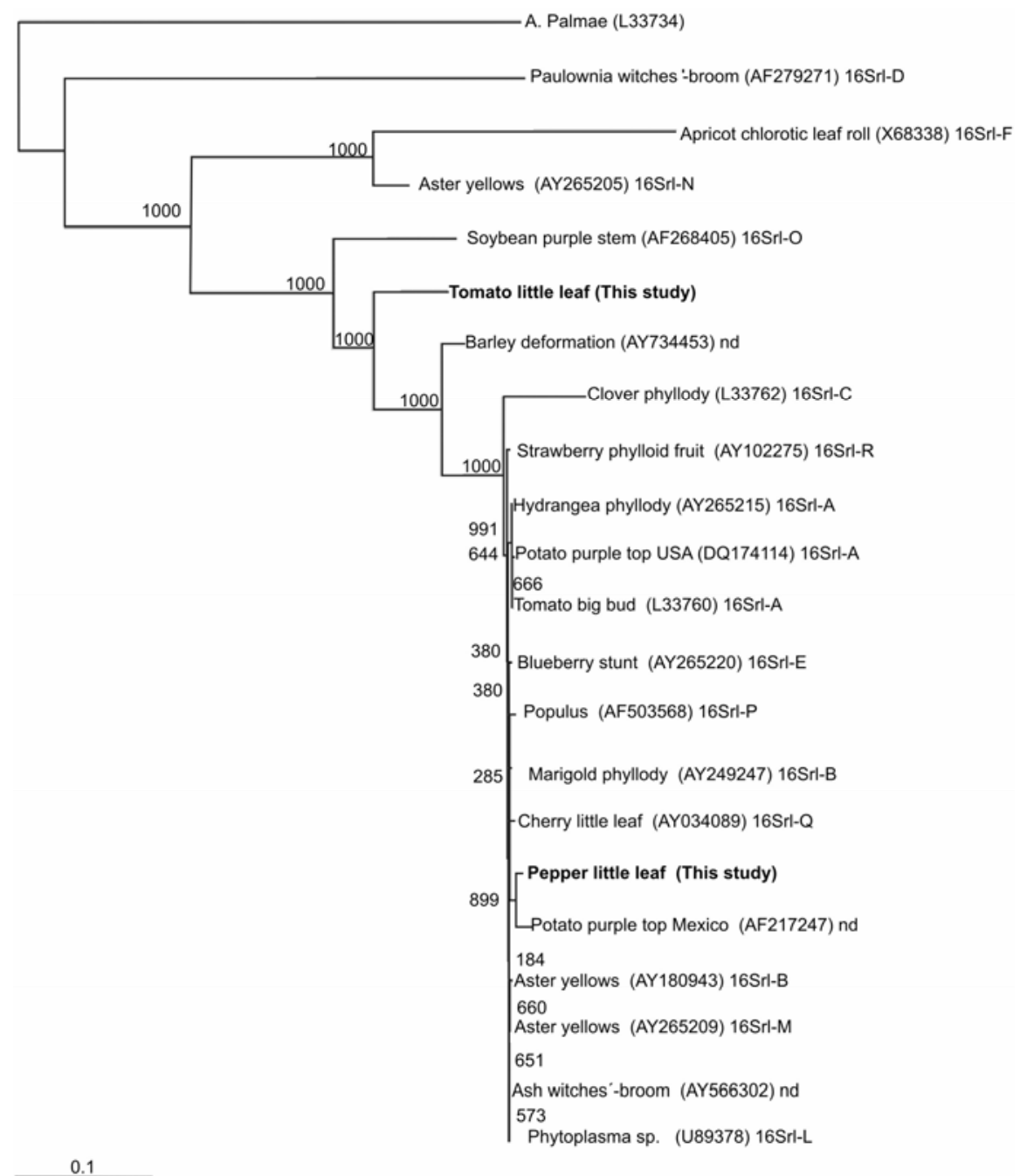

Fig. 4. Phylogenetic tree for the $16 \mathrm{SrI}$ rDNA group from 20 phytoplasmas. The tree was constructed using the neighbor-joining method. Acholeplasma palmae was used as the outgroup. The length of branches represents the distance between sequences. Bootstrap (confidence) values for 1,000 replications are shown on the branches. GenBank accession numbers for sequences are given in parentheses, followed by the phytoplasma subgroup. new subgroups in group 16SrI (aster yellows group).

\section{DISCUSSION}

Phytoplasma diseases of pepper have been reported in Australia, Spain, India, and Cuba $(7,8,20,37)$, and tomato in the United States, Australia, Italy, Jordan, Bolivia, and Brazil (3,4,11-13,19,22,24, $32,35)$. In this communication, we describe the discovery in Mexico of two new members of the aster yellows phytoplasma group (16SrI).

This work to identify and classify the causal agents of little leaf of pepper and tomato in Mexico was primarily based on RFLP analysis of PCR amplified rDNA, using the restriction endonucleases $A l u \mathrm{I}$, HpaII, KpnI, HaeIII, HhaI, and TaqI. This approach proved suitable for phytoplasma differentiation and preliminary classification of PeLL and ToLL phytoplasmas. The RFLP profile results were consistent with the phylogenetic tree and the virtual restriction patterns constructed with the $16 \mathrm{~S}$ rDNA gene sequence. We have placed the PeLL and ToLL phytoplasmas in new subgroups (I-S and I-T, respectively) of group 16SrI, indicating that they possess unique properties that are reflected in the results from enzymatic RFLP analyses, sequence similarities, and phylogenetic analysis based on 16SrRNA gene sequences. Other phytoplasma diseases detected in Mexico, potato purple top (PPT) and coconut lethal yellowing (LY), cause severe losses in potato and coconut crops $(16,27,29)$. In this study, we found that PeLL and ToLL phytoplasmas have a very close relationship with tomatillo little leaf phytoplasma reported previously in Mexico (31).

Although phytoplasmas were for a long time assumed to be the causal agent of the disease known in Mexico as "permanente" of tomato, molecular identification of the causal phytoplasmas was not previously attempted. However, a recent study indicated that $85 \%$ of symptomatic plants from the Baja California Peninsula of Mexico were PCR-positive, and that the rDNA had restriction patterns typical of phytoplasmas belonging to the aster yellows subgroup B (16SrI-B) ' $\mathrm{Ca}$. Phytoplasma asteris' and $10 \%$ were associated with a phytoplasma related to the 16 SrXIII-A Mexican periwinkle virescence group using the enzymes AluI, MseI, HhaI, and HpaII (17). The results of our studies indicated that phytoplasmas were present in $48 \%$ of the tomato samples tested and that these phytoplasmas belong to the $16 \mathrm{SrI}$ group.

On the basis of RFLP analysis, nucleotide sequence, and phylogenetic analysis, phytoplasmas associated with diseases of pepper and tomato in various countries have been classified in different $16 \mathrm{~S}$ rDNA groups: I, II, III, V, VI, XII, and XIII $(3,4,11,13,17,22,24,32,35)$. This indicates that phytoplasma diseases of pepper and tomato are genetically diverse. Therefore, 
DNA-based molecular techniques and computer analysis of the sequences obtained appear to be good methods for detecting and differentiating phytoplasma strains.

In Mexico, different phytoplasmas associated with plant diseases from 16S rDNA groups 16SrI (aster yellows) (27,30,31), 16SrII (peanut witches'-broom) (27), 16SrIV (16), and 16SrIX (pigeon pea witches'-broom) (28), have been characterized.

Identification of the causal agent of little leaf of pepper and tomato in Mexico should facilitate studies concerned with epidemic aspects of the disease, and could contribute to knowledge of the genetic diversity of phytoplasmas present in Mexico.

\section{ACKNOWLEDGMENTS}

We thank Instituto Politécnico Nacional, Fundación Produce Sinaloa, and Consejo Estatal de Ciencia y Tecnología del Estado de Sinaloa for the economic support of this research project. The work of Alicia Chávez-Medina was supported by a scholarship from Instituto Politécnico Nacional.

\section{LITERATURE CITED}

1. Alivizatos, A. S. 1989. Occurrence and distribution of tomato stolbur in Greece. Proc. Conf. Plant Pathogenic Bacteria, 7th. Budapest, Hungary 945-950.

2. Almeyda-León, I. H., Rocha-Peña, M. A., Piña-Razo, J., and Martínez-Soriano, J. P. 2001. The use of polymerase chain reaction and molecular hybridization for detection of phytoplasmas in different plant species in Mexico. Rev. Mex. Fitopatol. 19:1-9.

3. Amaral-Mello, A. P., Bedendo, I. P., Kitajima, E. W., Ribeiro, L. F., and Kobori, R. 2006. Tomato big bud associated with a phytoplasma belonging to group $16 \mathrm{Sr}$ III in Brazil. Int. J. Pest Manage. 52:233-237.

4. Anfoka, G. H., Khalil, A. B., and Fattash, I. 2003. Detection and molecular characterization of a phytoplasma associated with big bud disease of tomatoes in Jordan. J. Phytopathol. 151:223-227.

5. Arocha, Y., Antesana, O., Montellano, E., Franco, P., Plata, G., and Jones, P. 2007. 'Candidatus Phytoplasma lycopersici', a phytoplasma associated with 'hoja de perejil' disease in Bolivia. Int. J. Syst. Evol. Microbiol. 57:1704-1710

6. Arocha, Y., López, M., Piñol, B., Fernández, M., Picornell, B., Almeida, R., Palenzuela, I., Wilson, M. R., and Jones, P. 2005. 'Candidatus phytoplasma graminis' and 'Candidatus phytoplasma caricae', two novel phytoplasmas associated with diseases of sugarcane, weeds and papaya in Cuba. Int. J. Syst. Evol. Microbiol. 55:2451-2463.

7. Arocha, Y., Piñol, B., Picornell, B., Almeida, R., and Jones, P. 2007. Broad bean and sweet pepper: Two new hosts associated with ' $\mathrm{Can}$ didatus Phytoplasma asteris' (16SrI phytoplasma group) in Cuba. Plant Pathol. 56:345.

8. Castro, S., and Romero, J. 2002. The association of clover proliferation phytoplasma with stolbur disease of pepper in Spain. J. Phytopathol. 150:25-29.

9. Cervantes-Díaz, L., Zavaleta-Mejía, E., RojasMartínez, R. I., Alanís-Martínez, I., and Ochoa-Martínez, D. L. 2004. Primer reporte de la presencia de fitoplasmas en plantas de $\mathrm{Al}$ stroemeria sp. en Mexico. Rev. Mex. Fitopatol. 22:134-139.

10. Cicarrone, A. 1951. Sintomi di Virescenza ipertrofica (Big bud) del pomodoro nei pressi di Roma. Nota preliminare. Boll. Stazione Patol. Veg., Ser. 3. 7:193-197.

11. Del Serrone, P., Marzachi, C., Bragaloni, M., and Galeffi, P. 2001. Phytoplasma infection of tomato in central Italy. Phytopathol. Mediterr. 40:137-142.

12. Favali, A., Sanita di Toppi, L., Vestena, C., Fossati, F., and Musseti, R. 2001. Phytoplasmas associated with tomato stolbur disease. Acta Hortic. 551:93-99.

13. Gibb, K. S., Davis, R., and Constable, F. 1996. Tomato big bud phytoplasma. A widespread and "successful" phytoplasma in Australia. Int. Org. Mycoplasmol. Lett. 4:280.

14. Gundersen, D. E., and Lee, I. M. 1996. Ultrasensitive detection of phytoplasmas by nestedPCR assay using two universal primer pairs. Phytopathol. Mediterr. 35:144-151.

15. Gundersen, D. E., Lee, I. M., Schaff, D. A., Harrison, N. A., Chang, C. J., Davis, R. E., and Kingsbury, D. T. 1996. Genomic diversity and differentiation among phytoplasma strains in 16S rRNA groups I (aster yellows and related phytoplasmas) and II (X-disease and related phytoplasmas). Int. J. Syst. Bacteriol. 46:6475.

16. Harrison, N. A., Narváez, M., Almeyda, H., Cordova, I., Carpio, M. L., and Oropeza, C. 2002. First report of group 16 SrIV phytoplasmas infecting coconut palms with leaf yellowing symptoms on the Pacific coast of Mexico. Plant Pathol. 51:808.

17. Holguín-Peña, R. J., Vázquez-Juárez, R. C., and Martínez-Soriano, J. P. 2007. First report of a 16SrI-B group phytoplasma associated with a yellows-type disease affecting tomato plants in the Baja California Peninsula of Mexico. Plant Dis. 91:328.

18. IRPCM Phytoplasma/Spiroplasma Working Team - Phytoplasma Taxonomy Group. 2004. "Candidatus phytoplasma", a taxon for the wall-less, non-helical prokaryotes that colonize plant phloem and insects. Int. J. Syst. Evol. Microbiol. 54:1243-1255.

19. Jones, P., Arocha, Y., Antesana, O., Montellano, E., and Franco, P. 2005. "Hoja de Perejil" (parsley leaf) of tomato and morrenia little leaf, two new diseases associated with a phytoplasma in Bolivia. Plant Pathol. 54:235.

20. Khan, M. S., and Raj, S. K. 2006. First report of molecular detection of an aster yellows phytoplasma (Candidatus phytoplasma asteris) isolate infecting chili (Capsicum annuum) in India. Plant Pathol. 55:822.

21. Lee, I. M., Bottner, K. D., Secor, G., and Rivera-Varas, V. 2006. "Candidatus Phytoplasma americanum", a phytoplasma associated with a potato purple top wilt disease complex. Int. J. Syst. Evol. Microbiol. 56:15931597.

22. Lee, I. M., Davis, R. E., Chen, T.-A., Chiykowski, L. N., Fletcher, J., Hiruki, C., and Schaff, D. A. 1992. A genotype-based system for identification and classification of mycoplasmalike organisms (MLOs) in the aster yellows MLO strain cluster. Phytopathology 82:977-986.

23. Lee, I. M., Davis, R. E., and Gundersen, D. E. 2000. Phytoplasma: Phytopathogenic mollicutes. Annu. Rev. Microbiol. 54:221-555.

24. Lee, I. M., Dawn, E., Gundersen, D. E., and Davis, R. E. 1998. Revised classification scheme of phytoplasmas based on RFLP analyses of $16 \mathrm{~S}$ rRNA and ribosomal protein gene sequences. Int. J. Syst. Bacteriol. 48:1153-1169.

25. Lee, I. M., Gundersen, D. E., Davis, R. E., Bottner, K. D., Marcone, C., and Seemüller, E. 2004. "Candidatus Phytoplasma asteris", a novel phytoplasma taxon associated with aster yellows and related diseases. Int. J. Syst. Evol.
Microbiol. 54:1037-1048

26. Leyva-López, N. E., Aguilar-Rojas, O. I., LealKlevezas, D. S., and Martínez-Soriano, J. P. 1999. Presence of phytoplasmas in Mexican cacti. (Abstr.) Phytopathology 89:S45.

27. Leyva-López, N. E., Ochoa-Sánchez, J. C., Leal-Klevezas, D. S., and Martínez-Soriano, J. P. 2002. Multiple phytoplasmas associated with potato diseases in Mexico. Can. J. Microbiol. 48:1062-1068.

28. Luna-Esquivel, G., Rojas-Martínez, R. I., and Zavaleta-Mejía, E. 2004. Primer reporte del fitoplasma pigeon pea witches broom en Altamirano, Guerrero, México. Rev. Mex. Fitopatol. 22:125-128.

29. Martínez-Soriano, J. P., Leyva-López, N. E., Zavala-Soto, M. E., Berès, M., and LealKlevezas, D. S. 1999. Detección molecular del agente causal del síndrome "bola de hilo" de la papa en semillas infectadas y asintomáticas. Biotecnol. Apl. 16:93-96.

30. Rojas-Martínez, R. I., Zavaleta-Mejía, E., Lee, I. M., Martín, M., and Aspiros, H. S. 2003. Detection and characterization of the phytoplasma associated with marigold phyllody in Mexico. J. Plant Pathol. 85:81-86.

31. Santos-Cervantes, M. E., Chávez-Medina, J. A., Fierro-Coronado, J. A., Ruelas-Ayala, R. D., Barreras-Soto, M. A., Méndez-Lozano, J., and Leyva-López, N. E. 2007. First report of a Candidatus Phytoplasma asteris infecting tomatillo (Physalis ixocarpa) in Sinaloa, México. Plant Pathol. 56:721.

32. Saqib, M., Bayliss, K. L., and Jones, G. K. 2006. Identification of sweet potato little leaf phytoplasma associated with Vigna unguiculata var. sesquipedalis and Lycopersicon esculentum. Australas. Plant Pathol. 35:293-296.

33. Schneider, B., Ahrens, U., Kirkpatrick, B. C., and Seemuller, E. 1993. Classification of plant-pathogenic mycoplasma-like organisms using restriction-site analysis of PCRamplified 16S rDNA. J. Gen. Microbiol. 139:519-527.

34. Secretaría de Agricultura, Ganadería, Desarrollo Rural, Pesca y Alimentación (SAGARPA). Servicio de Información Agroalimentaria y Pesquera (SIAP). 2006. http://www.siap.gob.mx.

35. Shaw, M. E., Kirkpatrick, B. C., and Golino, D. A. 1991. Causal agent of tomato big bud disease in California is the beet leafhopper transmitted virescence agent. (Abstr.) Phytopathology 81:1210.

36. Tran-Nguyen, L., Balnche, K. R., Egan, B., and Gibb, K. 2000. Diversity of phytoplasmas in northern Australian sugarcane and other grasses. Plant Pathol. 49:666-679.

37. Tran-Nguyen, L., Persley, D. M., and Gibb, K. S. 2003. First report of phytoplasma disease in capsicum, celery and chicory in Queensland, Australian. Australas. Plant Pathol. 32:559560.

38. Valiunas, D., Staniulis, J., and Davis, R. E. 2006. "Candidatus phytoplasma fragariae", a novel phytoplasma taxon discovered in yellows disease strawberry, Fragaria $\times$ ananassa. Int. J. Syst. Evol. Microbiol. 56:277-281.

39. Vibio, M., Megliornldi, S., Lee, I. M., Davis, R. E., and Bertaccini, A. 1996. Genomic variability in $16 \mathrm{~S}$ rI-G phytoplasma infecting tomatoes in Italy and Bulgaria. Int. Org. Mycoplasmol. Lett. 4:260-261.

40. Zhang, Y. P., Uyemoto, J. K., and Kirkpatrick, B. C. 1998. A small-scale procedure for extracting nucleic acids from woody plants in fected with various phytopathogens for PCR assay. J. Virol. Methods 71:45-50.

41. Zimmermann-Gries, S., and Klein, M. 1978. A tomato big bud-like disease of tomatoes in Israel and its association with mycoplasma-like organisms. Plant Dis. Rep. 62:590-594. 